\title{
CFG 桩地基处理技术应用分析
}

\author{
余庆 \\ 陕西建工第十建设集团有限公司 \\ DOI:10.18686/bd.v2i8.1587
}

[摘要] 随着城镇化建设脚步的加快, 各种各样的新型城镇化建筑工程应运而生, 为人们提供住宿、工作等活动场所, 满 足人们的生活需求。但是现阶段, 由于建筑工程规模的庞大, 使得建筑工程在施工过程中对外部环境的改善工作变得越来 越重要, 也更加注重地基处理工作。基于此, 本文就对 CFG 桩地基处理技术应用对策进行探究, 以期为建筑工程地基施工 提供参考依据。

[关键词] 建筑工程; CFG 桩; 地基处理技术; 应用对策

现阶段,城市在发展过程中工程数量不断增多, 使得地 基处理工作变得越来越复杂,一旦地基处理工作不到位, 就 会造成建筑工程的承载力受到影响,埋下严重的安全隐患。 $\mathrm{CFG}$ 桩地基处理技术的应用刚好可以解决此种问题, 满足 人们对建筑物的多样化需求, 提高建筑工程建设质量。因 此,建筑工程中合理应用 CFG 桩地基处理技术是时代发展 的必然趋势, 本文就对 CFG 桩地基处理技术的应用对策进 行探究。

\section{$1 \mathrm{CFG}$ 桩地基处理技术的简单介绍}

CFG 桩地基处理技术英文名为“Cement Fly-ash Gravel Pile”, 翻译过来就是水泥粉煤灰碎石桩[1], 顾名思义, 就是 在地基施工中将碎石、石屑、砂、粉煤灰等众多材料掺和水 泥、水进行摚拌, 然后在使用成桩机械制成具有一定强度的 桩, 通过此桩可以快速将荷载传递到深层地基中去, 从而保 证各个桩之间的承载能力, 实现地基的处理工作。现阶段, 在建筑行业迅速发展的背景下, 建筑工程施工中经常会遇 到一些软土地基,软土地基地质条件差,空隙大、土质疏松 [2], 在施工过程中经常会遇到各种问题, 稍不注意, 就会埋 下严重安全隐患, 影响建筑工程的施工质量。针对此种情 况, 施工人员在建筑工程软土地基施工过程中就可以使用 CFG 桩地基处理技术, 根据工程施工具体情况, 科学合理 应用 CFG 桩地基处理技术, 对地基特殊地段进行适当处 理，通过 CFG 桩地基处理技术的应用减小软土地基的压缩 性, 提高地基的稳定性, 从而避免建筑工程后期投人使用后 出现地基下沉的问题, 保证建筑工程施工质量。

\section{2 水泥粉煤灰碎石桩的主要特点分析}

水泥粉煤灰碎石桩是一种粘结强度桩, 主要应用在高 层建筑、超高层建筑中, 在这些建筑工程中使用水泥粉煤灰 碎石桩, 可以充分做到裖垫层与基础的连接, 提高建筑工程 的承载能力[3]。通常情况下, 水泥粉煤灰碎石桩的主要特点 体现在以下几个方面:第一, 水泥粉煤灰碎石桩具有粘结度 高特点。众所周知, 水泥粉煤灰碎石桩是一种复合型桩, 在 使用过程中可以直接对地基进行处理，将众多材料进行混 合,组成强度在 $\mathrm{c} 5$ 至 C25 之间的混合材料[4], 此种材料一
旦投人使用, 就会保证桩之间的荷载能力符合要求, 提高建 筑工程地基承载能力。第二,水泥粉煤灰碎石桩具有价格便 宜性特点。建筑工程在地基处理工作中使用水泥粉煤灰碎 石桩可以避免以往工程施工中钢筋等众多材料的使用, 减 少施工成本支出, 在建筑工程地基施工中只使用水泥、粉、 煤灰、碎石等价格低廉的材料, 降低建筑工程地基施工阶段 的工程造价, 提高经济效益。第三, 水泥粉煤灰碎石桩具有 适用范围广的特点。建筑工程在施工过程中包含众多细小 的工程, 如, 房屋建筑工程、给排水工程等等, 这些细小的工 程中也会包含地基处理工作, 此种情况下, 建筑企业就可以 使用水泥粉煤灰碎石桩地基处理技术，保证这些细小工程 地基处理工作质量, 所以,水泥粉煤灰碎石桩具有使用范围 广的特点。

\section{CFG 桩地基处理技术的应用原理分析}

在建筑工程复合地基施工设计中, 建筑企业经常会在 基础与桩和桩间土之间设置一定厚度散体粒状材料组成的 裖垫层, 通过这个裖垫层对复合地基的受力情况合理控制, 让建筑工程各个桩间土载力的发挥可以不仅仅依赖于桩的 沉降, 而是由桩土共同承担, 保证复合地基承载能力符合建 筑工程施工要求。通常情况下, 建筑工程地基施工中应用 CFG 桩地基处理技术的原理主要体现在以下两个方面:一 方面, CFG 桩在使用过程中主体材料是碎石、石屑、粉煤 灰、水泥等等[5], 将这些材料进行混合, 混合完毕后形成一 定强度新型材料, 然后制作成 CFG 桩, 提高桩的强度, 满足 后续工程需求。另一方面, CFG 桩使用过程中受到材料的 压力经常会出现小范围的流动情况, 此种情况下, 就会导致 垫层材料发生移位, 降低桩的承载能力, 因此, 建筑企业需 要使用 CFG 桩进行置换工作, 合理调节渗透能力, 保证地 基周围土体不会发生松动, 提高建筑工程地基施工质量。

4 CFG 桩地基处理技术应用到建筑工程地基施工的 对策分析

$4.1 \mathrm{CFG}$ 桩地基处理技术的使用设备分析

建筑工程地基施工过程中经常会使用一些机械设备, 如, 振动沉管机、螺旋钻机等等, 一旦施工中这些机械设备 
性能不符合要求,直接影响建筑工程地基施工质量 [6]。因 此,建筑企业在建筑工程地基施工中应用 CFG 桩地基处理 技术就需要注重设备的选择工作, 具体可以从以下两个方 面进行机械设备的选择工作:一方面,建筑企业在机械设备 选择前期, 需要到建筑工程施工现场进行勘察, 详细了解建 筑工程地基情况, 根据建筑工程地基情况确定机械设备的 型号、大小、类型等内容, 保证所选择的机械设备能够在地 基施工中顺利使用。另一方面，建筑企业在使用机械设备 时, 需要对各种机械设备合理搭配, 避免单独使用振动沉管 机等设备, 保证建筑工程地基施工过程中不会出现桩体断 裂的情况。

$4.2 \mathrm{CFG}$ 桩地基处理技术的使用要点分析

建筑工程地基施工中经常会使用大量的施工材料、机 械设备等,一旦施工中不注意, 就会导致地基施工质量下降 [7]。因此,建筑企业在使用 CFG 桩地基处理技术过程中,需 要严格注意以下几点内容: 第一,地基施工中,需要合理控 制地基深度, 并对施工中保证拔杆速度与混合料百量的平 衡性,避免地基施工过程中出现停洜送料的问题。第二,施 工人员在展开沉管灌注桩施工时, 需要提前了解此阶段施 工流程、注意事项,并在施工过程中控制拔管速度,避免拔 管过程中出现桩端部位虚土、极端混合料离析等问题,造成 管口堵塞。第三,施工人员在使用 CFG 桩地基处理技术时, 需要合理控制施工过程中的混合料葲送能力, 并将混合料 的配比度控制在一个合理的范围内, 从而保证桩质量。

$4.3 \mathrm{CFG}$ 桩地基处理技术在地基强度恢复的应用

众所周知,建筑工程在地基施工过程中,由于施工人员 专业技术不成熟，在施工过程中经常会导致地基强度受到 影响, 针对此种情况, 建筑企业就需要使用 CFG 桩地基处 理技术对地基强度进行恢复，施工前期准确了解地基强度 和土体性质, 根据工程具体情况展开实际操作, 从而保证地 基强度顺利恢复,提高建筑工程地基施工质量。

加强 $\mathrm{CFG}$ 桩地基处理工作的质量检验

建筑企业要想保证地基施工质量, 就需要在地基施工 完毕后, 加强 $\mathrm{CFG}$ 桩地基处理工作的质量检验工作:一方
面,建筑企业需要对 CFG 桩地基处理工作中所涉及到的裖 垫层厚度、混合料塌落度等内容合理确定, 确保地基强度符 合要求。另一方面,建筑企业需要在地基施工过程中所产生 的数据资料进行认真记录, 然后根据所记录的数据确定桩 成桩的时间,再展开复合地基载荷试验工作,对符合地基反 复进行试验, 通过试验确定 CFG 桩强度是否符合要求, 一 旦 $\mathrm{CFG}$ 桩不符合要求, 及时更换, 避免出现更严重的质量 问题, 提高地基施工质量。

\section{5 结语}

总而言之, $\mathrm{CFG}$ 桩地基处理技术作为地基处理技术的 一种,具有技术性高、经济效果好、承载力强等众多特点,所 以,在建筑工程地基处理工作中最常使用。在科学技术不断 进步的背景下, CFG 桩地基处理技术也变得越来越成熟, 此种情况下, 施工人员就需要根据建筑工程地基施工具体 情况,科学合理的应用 CFG 桩地基处理技术,从而保证建 筑工程地基处理工作质量,助推建筑行业实现可持续发展。

\section{参考文献:}

[1]毛宏.铁路 CFG 桩地基处理技术的应用研究 [J].山 西建筑,2015,(18):76-77.

[2]化建新,间德刚,赵杰伟等.第七届全国岩土工程实录 交流会特邀报告——地基处理综述及新进展 [J]. 岩土工程 技术,2015,29(6):285-300.

[3]许兴旺.高速铁路 CFG 桩十挤密桩工程实践及研究 [J].铁道工程学报,2016,33(4):36-40.

[4]周洺汉,许燕群, 徐林荣等.高铁不同刚度桩一网复 合地基工作性状差异[J].土木建筑与环境工程,2017,39(5): 56-62.

[5]鲁爱民.强夯法 +CFG 桩在湿陷性黄土地区地基处 理中的应用[J].施工技术,2017,46(15):104-107.

[6]朱彦鹏,唐文斐.CFG 桩复合地基处理软弱路基沉降 机理[J].兰州理工大学学报,2015,41(4):117-120.

[7]史俊,王小勇.水泥粉煤灰碎石桩(CFG 桩)复合地基 在高层建筑地基处理中的应用 [J]. 安徽地质,2015,(1): $57-60$. 